FROM THE ARCHIVES

Ed. Alois Pichler

\title{
G. H. von Wright's Unpublished Edition of Wittgenstein's "Last Writings": Editors' Preface and Other Materials, ca. 1967-68
}

\author{
Edited and introduced by Lassi Jakola ${ }^{1}$ \\ lassi.jakola@iki.fi
}

\section{Abstract}

Part II of this contribution makes available materials preserved of G. H. von Wright's hitherto unknown edition of Ludwig Wittgenstein's last writings (1949-51) from 1967-68. The edition was never published. The underlying MS material (MS 169-177) was, instead, published in four different edited volumes in 1969, 1977 and 1992. Part I, an introduction to the archival items, contextualizes von Wright's edition historically, presents a reconstruction of its structure, compares it with the published volumes, and discusses reasons for its abandonment.

\footnotetext{
${ }^{1}$ The work on this article has been made possible by the project The Creation of Wittgenstein, funded by the Academy of Finland and directed by Prof. Thomas Wallgren, and by a personal research grant from Alfred Kordelin foundation. Anita von Wright-Grönberg and Benedict von Wright (the copyright holders of G. H. von Wright's writings and correspondence), have kindly given consent to the publication of the materials, and have allowed me to cite from von Wright's other unpublished writings and correspondence. I am indebted to Alois Pichler, Sebastian Grève and Peter Westergaard for valuable comments on the submitted version of this article, and to Peter Hacker, Joachim Schulte and Bernt Österman for observations on earlier drafts. Bernt Österman kindly provided me with high-quality scans of the original documents. Finally, thanks are due to Dr. Mary Geach (M. C. Gormally) for allowing me to quote from Elizabeth Anscombe's unpublished letters and to Prof. Volker Munz for allowing me to cite Rush Rhees' unpublished letters.
} 


\section{Editor's introduction}

The materials reproduced in Part II of this article are related to G. $\mathrm{H}$. von Wright's unpublished edition of Wittgenstein's writings from the years 1950-51. The edition was preliminary called "Last Writings" and was evidently at a fairly advanced stage in early 1968. The materials are kept at the von Wright and Wittgenstein archives (WWA) at the University of Helsinki (signum Witt-AM-F1). The existence of this edition has thus far been largely unknown to scholars. ${ }^{2}$ Part II of this article reproduces the following four preserved items from the edition as facsimile:

Item I. Vorwort der Herausgeber / Editors' Preface

Item II. A quotation from Wittgenstein's TS 222

Item III. Table of contents

Item IV. Preserved pages from the edition

In addition, a normalized English translation of the pages originally written in German is provided, along with a limited commentary in footnotes. Part I is an introduction to the archival materials. The introduction contextualizes the edition historically, presents a reconstruction of its structure, compares it with the published volumes, discusses reasons for its abandonment, and analyses some select questions related to the published items in more detail.

With the publication of these items, scholars will have access to prefaces or introductions written to Wittgenstein's last writings by each of his three literary executors. ${ }^{3}$ Wittgenstein's last writings

\footnotetext{
${ }^{2}$ The items have been falsely described in von Wright's own catalogue of his Wittgenstein materials, which characterizes the items as "Materials for the Last Writings on the Philosophy of Psychology. With GhvW's sketches of a preface and comments on the manuscripts. The book as then projected was never published" (WWA: Witt-000). The projected edition, however, is of Wittgenstein's last writings in general, not merely on materials later published in $L W 1$ and $L W 2$.

${ }^{3}$ G. H. von Wright's 1968 preface to the unpublished edition (published here), his 1972 article on On Certainty, and his (and Nyman's) 1992 preface to LW2; Elizabeth Anscombe's and von Wright's joint introduction to OC from 1969; Anscombe's 1977
} 
constitute a unique case in the editorial history of Wittgenstein's papers, as all the three heirs made substantial, and mutually differing, publication proposals concerning these materials. I have discussed and compared their proposals in another context: the function of this contribution is to make the preserved materials related to von Wright's edition available to the scholarly community. ${ }^{4}$

\section{Wittgenstein's last writings (1949-1951)}

G. H. von Wright's plan for an edition of Wittgenstein's last writings was never realized. The underlying manuscript materials from this period have, instead, later been made available in four edited and thematically organized and named books, namely:

1. On Certainty (1969, abbr. OC), edited by G. E. M. Anscombe and G. H. von Wright;

2. Remarks on Colour (1977, abbr. RoC), edited by Anscombe alone; 3. Vermischte Bemerkungen (1977, abbr. VB), edited by von Wright in collaboration with Heikki Nyman, and

4. Last Writings on the Philosophy of Psychology, Vol 2 (1992, abbr. LW2), edited by von Wright and Nyman.

Wittgenstein's 'last writings' (MSS 169-177) consist of the manuscripts Wittgenstein composed roughly during the last two years of his life, i.e. between 1949 and April 1951. ${ }^{5}$ These writings were never typed or dictated. Neither were they substantially revised or re-used in later manuscripts, with the major exception of the first part of RoC (MS 176), which is composed from remarks originally

preface to $\mathrm{RoC}$; and the posthumously published translation of Rush Rhees' introduction to the 1970 Suhrkamp edition of OC (in Rhees 2003).

${ }^{4}$ See my article “Approaches to Wittgenstein's 'Last Writings' (1949-51): Elizabeth Anscombe, G. H. von Wright and Rush Rhees in dialogue" (Jakola [to appear]), which is to appear as a chapter in the book The Creation of Wittgenstein (ed. Thomas Wallgren). The article's section on von Wright's edition contains some necessary overlap with Part I of this contribution.

${ }^{5}$ In this article, I am not concerned with the materials published under the title Last Writings on the Philosophy of Psychology, Vol 1. These writings (MSS 137-8) stem from a slightly earlier period, as they were written in Dublin in 1948 and early 1949. 'Last writings', as I am using the term here, were written (with the possible exception of MS 169) after Wittgenstein's trip to the United States in 1949. 
written in MS 173. As far as I know, these are mostly notebooks Wittgenstein either had with him at the time of his death at Dr. Bevan's house in Cambridge in April 1951 or which he had left at Miss Anscombe's flat at Oxford when moving to Cambridge in February 1951. At any rate, they were among the first items from Wittgenstein's Nachlass known to his literary executors. ${ }^{6}$

It is often said that the contents of these notebooks can be divided into three thematic complexes: remarks on knowledge and certainty, colours, and philosophy of psychology. This thematic division strongly informs the publication policy behind the posthumous editions. Even though this division has recently been questioned by many specialists, several prominent scholars have also accepted it.

\section{Von Wright's edition of "Last Writings": background and probable date}

Of Wittgenstein's three literary executors, G. H. von Wright was the driving force in preparing Wittgenstein's last writings for publication for most of the 1950s and 1960s. As early as 1954, he had publicly announced that plans have been made to publish some of Wittgenstein's late writings in print. $^{8}$ In January 1962, he finished a carefully typed transcription of MSS 168-171 and 173-177, then called the "Omega-volumes" by Wittgenstein's literary executors." This transcription was made on the basis of a photographic copy of the notebooks, bound in two big volumes, titled $\Omega 1$ and $\Omega 2$, made

\footnotetext{
${ }^{6}$ See von Wright (1982: 38); Anscombe (1977: Preface) and Paul (2007: 30, 292).

${ }^{7}$ The division into three themes was first introduced in Wright's 1962 introduction to his transcription of these notebooks (in WWA: Witt-AM-F1), and later repeated in the published prefaces to $O C, \mathrm{RoC}$, and $L W 2$. For criticism, see e.g. Stern (1996: 447), Westergaard (2019), Schulte (unpublished MS).

${ }^{8}$ See von Wright (1954: 20), i.e. the very first, Swedish publication of his much-read "Ludwig Wittgenstein: a biographical sketch".

${ }^{9}$ MS 172 was not included, as its existence was discovered later. A typed transcription of MS 172 was probably made in December 1964. See von Wright to Anscombe, 3 December 1964 (National Library of Finland [NLF]: The Georg Henrik von Wright Collection, Coll. 714, 11-12), where a reference to typed and copied "MS pages" is made, which von Wright considers "good on the whole" and as a possible "candidate for inclusion on our projected volume of last writings". Denis Paul (2007: 297) confirms that MS 172 was not available in the early 1950s and reports having received a photocopy in early 1967. His conjecture, however, that the MS was discovered only "shortly before" this date seems to be inaccurate.
} 
probably in the mid 1950s. ${ }^{10}$ In a 12-paged introduction to his transcription, von Wright carefully described each of the manuscripts, gave an overview of their contents, and provided a tentative dating of each item. ${ }^{11}$ Carbon copies of this transcription were sent to Anscombe in January $1962^{12}$ and via Norman Malcolm to Rush Rhees. ${ }^{13}$ Rhees's copy seems to be preserved at the Wren Library of Trinity college, Cambridge, and is to my present knowledge the only extant version of von Wright's transcription. ${ }^{14}$ This transcription was used as a basis for further editorial work. The contents of the planned edition were aired in several letters between von Wright, Norman Malcolm, Elizabeth Anscombe and Rush Rhees in the mid-1960s. ${ }^{15}$ Eventually, von Wright made up his mind concerning the structure of the edition around September 1967 May 1968, composing the materials reproduced in Part II.

None of the archival materials are dated. Item I, von Wright's "Vorwort der Herausgeber", can, however, fairly certainly be dated

\footnotetext{
${ }^{10}$ The photograph volumes are both preserved in the WWA: Witt-100-082 and Witt-100085.

${ }^{11}$ The introduction to "Omega-volumes" is also preserved in WWA: Witt-AM-F1, but no copy of the transcription itself is preserved in WWA. See note 14 below.

${ }^{12}$ See von Wright to Anscombe, 29 January 1962. National Library of Finland (NLF): The Georg Henrik von Wright Collection, Coll. 714, 11-12. Anscombe refers to this transcription in her 1977 Preface to RoC.

${ }^{13}$ von Wright to Rhees 29 Jan 1962. Malcolm, however, kept the copy for more than a year in Ithaca, studied it carefully, and delivered it to Rhees in September 1963. See Malcolm to von Wright 4 February 1963 and 10 July 1963, Rhees to von Wright 20 December 1963. NLF: The Georg Henrik von Wright Collection, Coll. 714, 142-148 and 200-201.

${ }^{14}$ In Trinity College's catalogue of Rush Rhees materials (retrieved from Jonathan Smith on 7 October 2020), there is an item S2, described as "Typescript of the 'omega volumes' together with an introduction by Rhees. Where remarks are deleted in the original, they are not transcribed (1 vol)". I am fairly certain that this item is, in fact, von Wright's 1962 transcription and that the "introduction" is a carbon copy of von Wright's introduction kept at WWA. If this is so, the item's introduction is falsely attributed to Rhees. This hypothesis is enforced by von Wright's catalogue of the 'Rhees materials', kept at WWA: Witt-500-12, in which the typescript of the Omega volumes (Box I, item 10) is attributed to von Wright. I have not yet been able to visit the archives at Cambridge to clarify and confirm the issue.

${ }^{15}$ The most substantive letter is von Wright to Anscombe, 11 June 1964. See also Malcolm to von Wright 10 July 1963, in which Malcolm suggests what of the late notebooks he finds worth publishing. NLF: The Georg Henrik von Wright Collection, Coll. 714, 11-12 and 142-148.
} 
to August 1967, for at the end of the month he writes to Elizabeth Anscombe:

I enclose a sort of a Preface which I have written for the volume, as I see it, of Wittgenstein's last writings" [...] [E]ven if you agree with my present opinion on the composition of the volume, you may disagree with my Preface - either in toto or in parts. You should then feel free to suggest alterations or to rewrite it completely. I have written it in German, but without a dictionary and competent aid, so the language needs a lot of polishing up and of correcting downright mistakes.

Preceding Item I in the same folder, there is also an earlier typed draft of a preface, with many hand-written corrections. This draft is not reproduced here. The main difference between the draft and Item $I$ is that, in the former, von Wright is still uncertain whether the materials on the 'Innen-Aussen' problem are to be included in the book. Because the draft is otherwise close to the later version, the draft was probably not written much earlier. It is not completely certain, which of these two versions was sent to Anscombe in August 1967, but my hypothesis is that it was Item I, not the draft. ${ }^{16}$ If these two conjectures are correct, we may infer that von Wright formed his opinion on the exact structure of the volume fairly late, in any case not much earlier than in August 1967. This gives us a terminus post quem for the edition.

As regards the date of the items II, III, and IV - a loose page, the Table of contents and the pages from the edition - von Wright's letter to Blackwell's Henry Schollick, dated 29 May 1968, reveals that the edition was at an advanced stage - "ready for printing" - in the Spring of 1968 at the latest.

Miss Anscombe and I have for years been planning and working on a volume of Wittgenstein's last writings. I have myself an opinion of its composition but Miss Anscombe, I understand, has not yet made up her mind. The problem is to decide what to include and what to omit. There exists an edited German text ready for printing. I have been waiting to hear from Miss Anscombe since last Autumn. I wish the matter were soon put in order. ${ }^{17}$

\footnotetext{
${ }^{16}$ Item I, too, contains some grammatical and stylistic mistakes in German, see e.g. p.3 "seinem [sic] Rückkehr". In the draft, the mistakes and corrections are so numerous that I doubt von Wright would have dared to send it to Anscombe.

${ }^{17}$ Von Wright to Schollick 29 May 1968, WWA: Wri-FC-016.
} 
On the basis of this evidence, von Wright's Vorwort (Item I) may be dated roughly to August 1967, while the items II - IV probably stem from the period between August 1967 and May 1968.

\section{The edition's contents and structure}

Von Wright's edition - i.e. "the edited German text ready for printing", mentioned in the letter to Henry Schollick, quoted above - has not been preserved in its entirety in the archives. Only random pages from section breaks and from the ends and beginnings of undersections have been preserved. They are all reproduced in Item IV. The edition's contents can, however, fairly easily be roughly reconstructed on the basis of the preserved materials, especially items III and IV. ${ }^{18}$ My hypothetical reconstruction of the edition's structure is presented in Table 1, below, where I supplement the information given in Items III and IV with probable MS sources and with corresponding sections in the published work. I also comment on how each section is marked or separated from other sections in Wittgenstein's MSS.

I. INNEN-AUSSEN, PP. 1-26.

\begin{tabular}{|c|c|c|c|c|}
\hline & GHvW's Table of Contents & $M S$-source & In editions: & Comment by L.J: \\
\hline I.i & Pp. 1-11. April 1950 (са.) & $\begin{array}{l}\text { MS 173, 31v- } \\
47 \mathrm{v}\end{array}$ & $\begin{array}{l}L W 2 \text { iv, pp. 61- } \\
71\end{array}$ & $\begin{array}{l}\text { The section is separated } \\
\text { with horizontal lines in } \\
\text { the MS. The later part of } \\
\text { MS } 173 \text { (pp. } 87 \mathrm{r}-100 \text { ), } \\
\text { published both in } R o C \text { III } \\
\S \S 296-350 \text { ) and } L W 2 \text { iv, } \\
\text { pp. } 71-79 \text {, was clearly } \\
\text { not included in this } \\
\text { proposal. Otherwise } \\
\text { more pages should have } \\
\text { been reserved for this } \\
\text { section. }\end{array}$ \\
\hline
\end{tabular}

\footnotetext{
${ }^{18}$ It is possible that von Wright's 1962 transcription of the "Omega Volumes" could offer the key to reconstructing the edition more accurately, as von Wright may have used a copy of this transcription in preparing the edition, selecting and re-organizing its pages. This hypothesis is based on the following observation: The preserved loose pages in Item IV all stem from an end or a beginning of a new section, and they do not always reproduce whole remarks. This may indicate that the pages were retyped to establish first or final pages for given sections of the edition, which otherwise used pages from some earlier TS. See note 14 , above.
} 


\begin{tabular}{|l|l|l|l|l|}
\hline I.ii & $\begin{array}{l}\text { Pp. 12-22. April 1950, or } \\
\text { later. }\end{array}$ & MS 174, 1-14 & $\begin{array}{l}\text { LW2 v, pp. 81- } \\
90\end{array}$ & $\begin{array}{l}\text { The section is separated } \\
\text { from the following } \\
\text { remarks (=III.ii below) } \\
\text { with a double horizontal } \\
\text { line in the MS. }\end{array}$ \\
\hline I.iii & Pp. 23-26. April 1951 & $\begin{array}{l}\text { MS 176, 46v- } \\
51 \mathrm{v}\end{array}$ & $\begin{array}{l}\text { LW2 vi, pp. 92- } \\
95\end{array}$ & $\begin{array}{l}\text { The section is separated } \\
\text { with horizontal lines } \\
\text { within III.iv in the MS. }\end{array}$ \\
\hline
\end{tabular}

II. COLOUR, PP. 27-40.

\begin{tabular}{|l|l|l|l|l|}
\hline & GHvW's Table of Contents & MS-source & In editions: & Comment by L.J: \\
\hline II.i & $\begin{array}{l}\text { pp. 27-40. Probable date: } \\
\text { Summer 1950 }\end{array}$ & MS 176,1-22r & RoC I, §§1-88 & $\begin{array}{l}\text { Not typographically } \\
\text { separated in the MS, but } \\
\text { the section is, on } \\
\text { chronological and text- } \\
\text { genetical grounds, } \\
\text { almost certainly earlier } \\
\text { than the rest of MS 176 } \\
\text { (III.iv below), which is } \\
\text { direct continuation of } \\
\text { MS 175. }\end{array}$ \\
\hline
\end{tabular}

III. KNOWLEDGE AND CERTAINTY, PP. 41-149.

\begin{tabular}{|c|c|c|c|c|}
\hline & GHvW's Table of Contents & MS-source & In editions: & Comment by L.J: \\
\hline III.i & $\begin{array}{l}\text { pp. 41-52. January - March } \\
1950 .\end{array}$ & MS $172,1-20$ & OC $\S \S 1-65$ & $\begin{array}{l}\text { Four pages from MS } 172 \\
\text { are published as Part II } \\
\text { of } R o C \text { and were not } \\
\text { included in von Wright's } \\
\text { edition. }\end{array}$ \\
\hline III.ii & $\begin{array}{l}\text { pp. 53-72. April 1950, or } \\
\text { later. }\end{array}$ & $\begin{array}{l}\text { MS } 174,14 \mathrm{v}- \\
40 .\end{array}$ & OC $\$ \$ 66-192$ & $\begin{array}{l}\text { The section is separated } \\
\text { with a double horizontal } \\
\text { line from the preceding } \\
\text { remarks (= I.ii. above) }\end{array}$ \\
\hline III.iii & $\begin{array}{l}\text { pp. } 73-87 . \text { September } 1950 \text {, or } \\
\text { earlier. }\end{array}$ & MS $175,1-34 v$ & OC $\S \S 193-299$ & $\begin{array}{l}\text { The section is separated } \\
\text { from the later remarks in } \\
\text { MS } 175 \text { (III.iv below) by } \\
\text { allegedly being many } \\
\text { months earlier. }\end{array}$ \\
\hline III.iv & $\begin{array}{l}\text { pp. 88-149. March } 101951- \\
\text { April 29, } 1951\end{array}$ & $\begin{array}{l}\text { MS } 17535 \mathrm{r}-79 ; \\
\text { MS } 176,22 \mathrm{r}- \\
46 \mathrm{v} ; 51 \mathrm{v}-81 \\
\text { and MS } 177,1- \\
11 .\end{array}$ & OC $\$ \$ 300-676$ & $\begin{array}{l}\text { The dates reveal this as a } \\
\text { temporally consecutive } \\
\text { sequence. Section I.iii, } \\
\text { above, occurs within this } \\
\text { section, but is marked } \\
\text { with horizontal lines. }\end{array}$ \\
\hline
\end{tabular}

Table 1. The structure of the edition 


\section{Von Wright's edition and the published editions: similarities and differences}

We may compare von Wright's edition's structure with the three major posthumous editions from the same source manuscripts by means of a visual graph. In the source-graph, the source manuscripts (MSS 169-177) are represented in the middle in their likely chronological order by horizontal bars, the lengths of which represent the relative lengths of the manuscripts. The sections published in von Wright's edition (the bars above) are indicated with plain colours, which stand for the thematic organisation into three complexes: psychology (blue), colours (red), epistemology (green). The bars below stand for $O C, \mathrm{RoC}$ and $L W 2$. The MS-sections published only in the three published volumes are indicated with screened colours. The arrows indicate the process of selection and reorganisation of the MS-sections. Exact MS page numbers for von Wright's edition are given in Table 1 of the preceding section. ${ }^{19}$

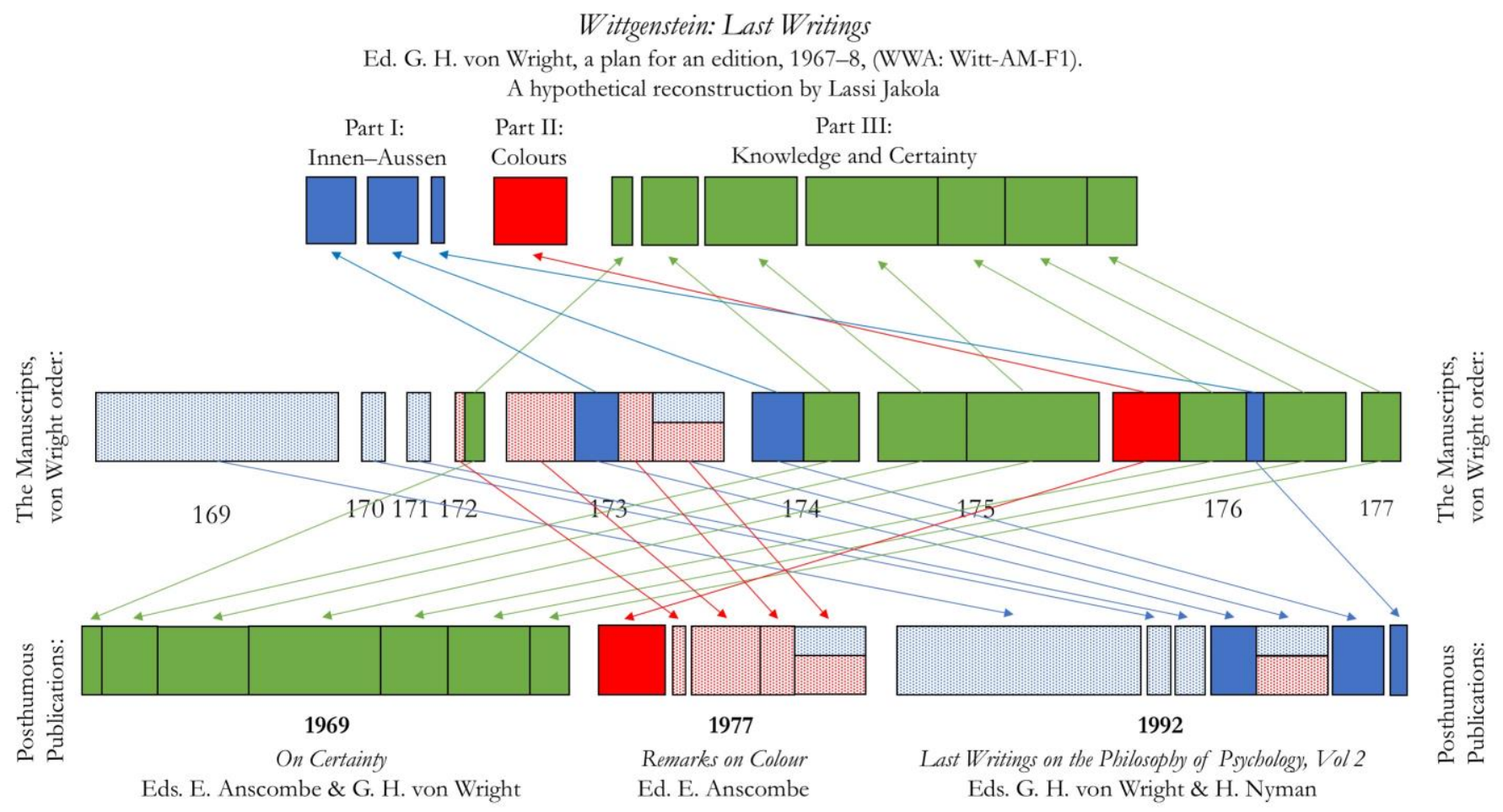

Source-graph 1. Von Wright's edition in comparison with $O C, \mathrm{RoC}$ and LW2

\footnotetext{
${ }^{19}$ In Jakola (to appear) I present similar source-graphs of each posthumous edition, with more information. For the exact MS sources of the posthumous editions, see e.g. Pichler (1993), Rothhaupt (1996: 368) and Rogers (2011: 76).
} 
As is clear from the reconstruction, von Wright's edition contained, as part III, the whole of what was later published as On Certainty; as part II, the later Part I of Remarks on Colour, and as part I, two and a half sections of the later Last Writings on the Philosophy of Psychology, Vol 2. Like the later editions, von Wright's edition, too, reproduced longer chunks of remarks from Wittgenstein's notebooks. In fact, it seems that the 'sections' identified and used by von Wright are identical to those used later in the published volumes. But the edition was not as comprehensive as the four published volumes taken together, which reproduce, in an edited arrangement, almost everything from Wittgenstein's late notebooks. While von Wright's edition seems to have reproduced everything Wittgenstein wrote on knowledge and certainty in 1950-51, it would have offered only briefer summaries of Wittgenstein's remarks on the two other topics, i.e. on colours and on psychological concepts. The editorial approach was thus selectively selective. In consequence, the edition would have provided the readers a somewhat unbalanced idea of the relative proportions of the three themes treated in Wittgenstein's last writings.

In accordance with the guiding idea followed in the published volumes, the contents of von Wright's edition were divided into three thematic sections, thus breaking the order of the stretches of remarks in the MS notebooks. While this thematic division may reasonably be questioned, it does have a tentative basis in Wittgenstein's manuscripts: the divisions introduced by von Wright and Anscombe in their later editions often either follow horizontal lines used by Wittgenstein himself or are based on text-critically established probable dates of the sequences of remarks (see my comments in Table 1, above and, as an example of the latter kind of reasoning, section $\mathrm{I} .7$, below).$^{20}$ As regards such sigla in MSS, von Wright's edition seems to be on safer ground than the published editions in dividing the material into thematic sections. ${ }^{21}$ In

\footnotetext{
${ }^{20}$ For criticism of interpreting the horizontal lines as thematic breaks, see van Gennip 2003.

${ }^{21}$ Von Wright's 1968 proposal excluded MS 169-171, which were later to be published in LW2. It also excluded the first and third part of MS 173, published later as RoC III and the fourth part the same notebook, published both in RoC III and $L W 2$. The latter part of MS 173 contains no sigla by Wittgenstein dividing the remarks into two categories.
} 
comparison with $O C$, the edition indicates more clearly where each section and subsection begins and ends, also giving the probable dates of each section. The sub-sections in each thematic part are organized chronologically.

As is evident from the preserved pages, ${ }^{22}$ the edition also followed the practice adopted by the editors in their earlier editions from Wittgenstein's Nachlass: textual variants were chosen by the editors and the text was offered to the reader "in as 'naked' a form as possible, with a minimum of footnotes or other visible learned apparatus" (von Wright 1982, 5). As we don't have access to a full copy of this edition, it is not possible to say which alternatives were chosen and whether the text was identical to the corresponding passages published in the later volumes. Neither do we know whether some singular remarks were omitted and whether these omissions are the same as in the posthumous publications.

In contrast to the published editions, von Wright's edition would have brought together, in one single volume, materials from all the three thematic complexes with which Wittgenstein was preoccupied during his last years. And even more importantly, it would have done this on one single rather than on three separate occasions. This, I believe, is the most important difference to the actual publication program, where the tripartite thematic selection is reflected in a tripartite separation into different publications. Having the materials made available in one collection would certainly have prompted scholars to interpret the topics in connection with one another. Such comparative studies were, indeed, practically impossible until 1992, when $L W 2$ was published - and even then, it was unclear how the different chains of remarks published in different books were interrelated in the MS sources.

Another difference concerns the numbering of singular remarks. On the basis of the preserved pages in Item IV, it seems that von Wright did not intend to give Wittgenstein's remarks a running numbering. Even though singular remarks are typographically separated in Wittgenstein's manuscripts with a blank line, the numbering was added to $O C$ and $\mathrm{R} o C$ by the editors. It may thus be

\footnotetext{
${ }^{22}$ Compare e.g. the page 88 of the edition below with the MS source MS 175, 35r: there are textual variants in the MS, which are not reproduced in the edited text.
} 
that, in this respect, von Wright's 1968 edition would have been closer to his 1977 edition of Vermischte Bemerkungen and his and Nyman's 1992 edition of LW2, in which the remarks are not numbered. A possibility that a numbering might have been added at a later stage in the editorial process cannot, however, be excluded.

A third major difference worth mentioning is that $O C, \mathrm{Ro} C$, and $L W 2$ were all named after the themes they were supposed to concern. Von Wright's edition, in contrast, had a more neutral title "Last Writings". By naming the published volumes as they did, the editors surely gave the readers some expectations as to what to expect from the books. ${ }^{23}$

\section{The fate of the edition: Anscombe's alternative vision in September 1968}

Even though it was G. H. von Wright who mostly advanced the work on Wittgenstein's 'last writings' in the early to mid-1960s, the letters quoted in Section 2 above testify that the editorial project was meant as a collaborative undertaking between him and Elizabeth Anscombe. Anscombe had been somewhat critical of von Wright's proposal already after seeing his sketch for a Preface in September 1967. On 13 September she replied to von Wright that she is "against a scrappy publication" when they "have a single treatise on a single topic to put before the public". ${ }^{24}$ While she does not elaborate her view further in the letter, the formulation implies that Anscombe tended to view Wittgenstein's notes on knowledge and certainty as an unfinished philosophical treatise of its own - and this was the format in which she wanted to present it to the philosophical public. Finally, in September 1968, she made an editorial proposal of her own. In a letter to von Wright, she insisted on publishing Wittgenstein's writings on knowledge and certainty as "monograph

\footnotetext{
${ }^{23}$ Joachim Schulte has recently (unpublished MS: 23-28) suggested that the editors, in dividing the material and naming the published volumes as they have done, have given a certain thematic orientation to the readers, which may have made it difficult to see interconnections between the treated topics.

${ }^{24}$ Anscombe to von Wright, 13 September 1967. NFL: The Georg Henrik von Wright Collection, Coll. 714, 11-12.
} 
of its own", and suggests reserving other materials for later publications:

[...] I went ahead with the certainty thing as a monograph on its own, as

I always wanted it to be. I hope you will agree that this was right. ${ }^{25}$

Anscombe seems to have been fairly adamant with her vision. ${ }^{26}$ As we know, this vision was, eventually, also realized: On Certainty was published in 1969 with Anscombe's new Preface, signed by both her and von Wright. ${ }^{27}$

Though von Wright was initially sceptical concerning Anscombe's proposal, ${ }^{28}$ he did not veto her publication plan. On the contrary, he soon changed his mind. After having studied the proofs for the upcoming On Certainty, he shared his impressions with Anscombe:

I am now completely convinced that you were right (against me) in insisting that the writings on certainty should be published as a book of its own. The impression it makes is strong and wonderful - in spite of certain repetitiveness and occasional "drops" to levels of not so high quality. ${ }^{29}$

It is as if von Wright only realized the high quality of Wittgenstein's remarks on knowledge and certainty when he saw the materials edited together to form a single, thematic whole. A year and a half later, he himself was one of the first authors who presented Wittgenstein's thoughts on this topic to the public in a

\footnotetext{
${ }^{25}$ Anscombe to von Wright, 16 September 1968. NLF: The Georg Henrik von Wright Collection, Coll. 714, 11-12.

${ }^{26}$ In 1970, too, when Rush Rhees proposed publishing the German edition of Über Gewißheit together with Lecture on Ethics and Remarks on Frazer's Golden Bough, Anscombe vetoed emphatically against Rhees' idea. Commenting Anscombe's decision to von Wright, Rhees reports that Anscombe "feels strongly that the remarks 'On Certainty' [...] should appear by themselves" (Rhees to von Wright, 19 March 1970, WWA: Wri-FC004). For details, see Westergaard 2017: 289.

${ }^{27}$ On the history of this preface, originally written in English and translated into German by Anselm Müller, see Anscombe to von Wright, no date 1969, von Wright to Anscombe 7 April 1969, von Wright to Malcolm 10 January 1970. NLF: The Georg Henrik von Wright Collection, Coll. 714, 11-12 and 142-148.

${ }^{28}$ Von Wright to Anscombe 21 September 1968. NLF: The Georg Henrik von Wright Collection, Coll. 714, 11-12.

${ }^{29}$ Von Wright to Anscombe 10 March 1969. NLF: The Georg Henrik von Wright Collection, Coll. 714, 11-12.
} 
philosophical gathering organized in Helsinki in August $1970,{ }^{30}$ later published as "Wittgenstein on Certainty" in 1972 (reprinted in von Wright 1982). Given the structure of von Wright's own edition and his thorough knowledge of the MS sources, this article contains some fairly strong formulations. In the first paragraph, von Wright $(1972,165)$ claims that "[d] uring the last year and a half of his life Wittgenstein wrote almost exclusively about knowledge and certainty" and argues that the remarks published in the book "possess a thematic unity which makes them almost unique in Wittgenstein's whole literary output". Both claims are surprising, given that von Wright very well knew that many notebooks written in 1950-1951 either were wholly concerned with, or contained longer stretches of remarks on colours [MS 172, MS 173, MS 176] or psychological concepts [MS 173, MS 174, MS 176]. With such formulations, von Wright thus actively supported the publication format suggested by Anscombe, and has, more indirectly, promoted the idea of On Certainty as late 'work' of Wittgenstein. ${ }^{31}$

While the quality of Wittgenstein's remarks was certainly one reason why von Wright admired On Certainty, it is possible that he, along with Anscombe, eventually welcomed the idea of introducing Wittgenstein's ideas in a thematic format which resonated with the contemporary philosophical discussions of the late 1960s. After all, in making Wittgenstein's thought available, one highly relevant consideration is the interest of the public, to which the thoughts are presented. From this perspective, it may have been a smart move to introduce the book as a critical answer to G. E. Moore's ideas, as is done both in the book's final Preface and in von Wright's 1972 article. (Interestingly, Moore is not mentioned in von Wright's preface to the 1967-8 edition, see Part II, Item I below.) In the final section of his 1972 article, von Wright also proceeds to connect Wittgenstein's late ideas with recent developments in the sociology of knowledge, naming Thomas S. Kuhn's ideas on the structure of scientific revolutions as an example. Though in a discreet manner, von Wright

\footnotetext{
${ }^{30}$ The gathering, organized by Institut International de Pbilosopbie on 24-27 August 1970, focused on Problems in the Theory of Knowledge. I have pointed out some interesting differences between the original presentation and the article published in 1972 in Jakola (to appear).

${ }^{31}$ See also von Wright (2001: 151-2).
} 
and Anscombe thus gave the book's readers a framework in which to locate and interpret Wittgenstein's late remarks. The picture they provide is that of a relatively 'self-contained' chain of remarks on epistemological issues, which are mainly addressed to Moore's suggestions. But while this editorial choice may have prompted more philosophers to study Wittgenstein's work, it simultaneously also discreetly detached the published remarks from the context of Wittgenstein's later philosophy. ${ }^{32}$

\section{Later developments of von Wright's views}

Despite the fact that von Wright accepted Anscombe's approach to publishing Wittgenstein's last writings, his own relation to the chosen publication program seems to be complex. In many contexts, he stressed that thematic 'compartmentalization' goes against the grain of Wittgenstein's way of viewing philosophy as an enterprise, where - as he once put it - "everything [...] is connected with everything else". ${ }^{33}$ Von Wright's initial enthusiasm concerning the qualities of $O n$ Certainty certainly did not mean that he would have abandoned the idea of publishing further materials from Wittgenstein's late notebooks. In the late 1960s, he was hoping to see further materials published soon. ${ }^{34}$ It was, however, to take eight years before the next volumes, $\mathrm{R}_{0} C$ and $V B$ came out (1977), and 23 years before $L W 2$, the final publication in the series, was published (1992). ${ }^{35}$ This exceedingly long waiting time - occasionally a cause of

\footnotetext{
${ }^{32}$ Such criticism was, indeed, raised by Rush Rhees in correspondence with von Wright in 1969, see Rhees to von Wright 18 June 1969 (WWA: Wri-FC-004). Concerning Rhees' perspective, see Westergaard (2017).

${ }^{33}$ Von Wright (1982: 139) and compare WWA: Wri-SF-064-c, an earlier draft of von Wright (1972). See also my discussion of this ambivalence in Jakola (to appear).

${ }^{34}$ See, for example, von Wright's letter to Norman Malcolm 5 March 1969. Commenting favourably on Anscombe's editorial proposal, von Wright hopes that the "stuff on colour, which is not included, can perhaps be published as an essay in the [Philosophical] Review." A similar suggestion is made in von Wright to Anscombe 10 March 1969. (NLF: The Georg Henrik von Wright Collection, Coll. 714, 11-12, and 142-148.)

35 The edition was ready for print in the early 1980s, but the publication was delayed due to Anscombe's disputes with the two main publishing houses, Blackwell and Suhrkamp. The dispute concerned royalties and general publication policy. As a consequence, the publication program of Wittgenstein's writings came to a halt for most of the 1980s. See, e.g., Anscombe's and von Wright's correspondence in June-July 1982 (NLF: The Georg Henrik von Wright Collection, Coll. 714, 11-12).
} 
great distress for von Wright - also somewhat changed von Wright's mind concerning the format of publication. One could say that, eventually, he returned to his earlier position that Wittgenstein's last writings ought to be published in one single volume, thus casting some doubts on the editorial choices made in late 1968. He did not, however, return to his 1968 edition. Rather, in the late 1980s, he came to think that the late notebooks should eventually be published as they are, with minimal editorial intervention. In 1988, von Wright supported an initiative of Suhrkamp Verlag of publishing a special facsimile edition of Wittgenstein's last manuscripts to celebrate Wittgenstein's centennial anniversary. (Nothing came out of this plan, however.) Writing to Rhees in May 1988, he explained:

The division of the material into three parts, those published as "[Ü]ber Gewissheit" and "Bemerkungen über die Farben" and the one which, hopefully, will soon appear as the second volume of the "Letzte Schriften über die Philosophie der Psychologie", is inevitably to some extent arbitrary, and I think it is of real interest to see and to read the material in toto in its original arrangement. ${ }^{36}$

In a sense, then, Last Writings on the Philosophy of Psychology, Vol 2 was, in von Wright's eyes, somewhat outdated already at the time of its publication in 1992. After the publication of $L W 2$, von Wright soon reconsidered the status of $O C, \mathrm{RoC}$, and $L W 2$ in a comprehensive plan for a revised edition of Wittgenstein's writings, preserved at the von Wright archives in Helsinki. ${ }^{37}$ Interestingly, in this plan, entitled "Wittgenstein re-edited", Vol. XVI was supposed to replace $O C, \mathrm{RoC}$, and $L W 2$ altogether. The volume was simply to contain MSS 170-177 in a re-edited form, allegedly in the hypothetical temporal order of the notebooks. ${ }^{38}$ This idea of having the notebooks published in toto in their original order is, however,

\footnotetext{
${ }^{36}$ von Wright to Rhees 24 May 1988, WWA: Wri-FC-006.

${ }^{37}$ WWA: Witt-AM-H9. This item is not dated. The same folder contains a similar plan from 1982, where no alterations are suggested to $O C, \mathrm{RoC}$, and $L W 2$. I submit that the undated version is later and stems probably from the 1990s. A likely terminus post quem is actually as late as 1992, since the plan refers to $L W 2$ as being already published. I thank Peter Westergaard for reminding me of the existence of this item and Anthony Kenny for a discussion concerning its dating.

${ }^{38}$ MS 169, now published as part I of $L W 2$, was possibly to be relocated to item XIV "Bemerkungen über die Philosophie der Psychologie III" where it would have been published together with the contents of $L W 1$.
} 
substantially different both from von Wright's abandoned 1968 edition and from the editions as we know them.

\section{A note concerning Item II: A motto?}

Item II, included in the file between the editors' preface and the table of contents, presents a puzzle. It is a loose, typed sheet, containing a remark from Wittgenstein's TS 222. ${ }^{39}$ TS 222 is a collection of cuttings, which forms the basis for RFM, part I. In 1968, as von Wright was working on his edition of last writings, this remark had not yet been published. Later on, it was added to the revised edition of RFM as the final remark $\$ 171$ of part I. Allegedly, the editors had difficulties with the remark, as it presents a musical analogy and seems to be detachable from the context of the other remarks contained in the same collection. ${ }^{40}$

We do not know with certainty why this sheet was included. No reference is made to it in other materials. But since von Wright himself often used quotations from Wittgenstein - and other writers - as mottos for his own work, ${ }^{41}$ it does not seem far-fetched to presume that this passage was likely meant as a motto for the whole 1968 edition. In the passage, a connection [of an unspecified topic or remark] is established with an aesthetical question related to the sequence of musical themes:

(Connected with this: We should sometimes like to say "There must surely be a reason why-in a movement of a sonata, for example-just this theme follows that one." What we should acknowledge as a reason would be a certain relation between the themes, a kinship, a contrast or the like.-But we may even construct such a relation: an operation, so to speak, that produces the one theme from the other; but this serves only when this relation is one that we are familiar with. [...]

\footnotetext{
${ }^{39} \mathrm{http}: / /$ www.wittgensteinsource.org/BFE/Ts-222,148 f and http://www.wittgensteinsource.org/BFE/Ts-222,149 f (accessed 15.5.2021).

${ }^{40}$ This, at any rate, is the reason given in a footnote to the revised 1974 Suhrkamp edition of the book (=Wittgenstein 1974), in which this remark is published as the final remark of Part 1, numbered \$171: "Ihr Platz in der Zettelsammlung ist aber nicht ganz klar und deshalb hatten die Herausgeber die Bemerkung nicht in die Erstausgabe aufgenommen. Es ist unsicher, ob ,Damit hängt zusammen' sich auf die vorhergehenden Bemerkungen 169 und 170 bezieht."

${ }^{41}$ E.g. Intellectual Autobiography, part III (= von Wright 1989), Explanation and Understanding, (= von Wright 1971) and In the Shadow of Descartes (= von Wright 1998).
} 
What we make of this remark is to a great degree dependent on the immediate context where it occurs: already the first indexical expression "Connected with this" refers to something outside the remark itself, and the musical analogy formulated in the remark may easily be used to illuminate several issues. By separating the remark and by putting it in front of his edition, von Wright surely made his own use of it. If the passage is indeed meant as a motto, it seems likely that, in this particular context, von Wright used it to allude to the connections between the three thematic complexes of the late notebooks - philosophy of psychology, colours, and certainty. If this is so, the passage serves here as a heuristic remark concerning thematic connections between Wittgenstein's late philosophical remarks. Perhaps it was meant as a kind of reminder to the reader that the order in which Wittgenstein moves from one topic to another, which may seem haphazard to some, may, after all, have a point. We must also bear in mind that there are some affinities between musical composition and Wittgenstein's own way of composing philosophical works from shorter philosophical remarks. Thus, questions typically framed in the aesthetics of music, like "why is this theme followed precisely by this theme", may find a meaningful application in understanding thematic 'transitions' in Wittgenstein's philosophy. One may, for example, ask - as is suggested in the final paragraph of the remark:

$[\mathrm{W}]$ hat arrangement of themes together has a point, and what has no point? Or again: Why has this arrangement a point and this one none? That may not be easy to say! Often we may say: "This one corresponds to a gesture, this one doesn't."

If we understand the remark as a motto alluding to the editor's approach, then von Wright's guiding idea may have been something like this: From an editor's point of view, to construct and think out a relation between given topics is a task better left to the reader. But the reader may construct such a relation only if the themes are presented together by the editor. For if they are not even presented together, it is likely that no-one will even bother to ask for a reason why a given theme is followed by another. 


\section{A note concerning the dating of MS 176, pp. 1-22r}

Finally, as an example of the complexities related to the editorial practices of Wittgenstein's late notebooks, I should like to discuss an interesting difference of opinion between von Wright and Elizabeth Anscombe. The dispute concerns the exact date of the first part of MS 176 (pp. 1-22r), published by Anscombe as RoC, part I, and which contains the later and revised version of Wittgenstein's writing on colours. This section was included in von Wright's 1968 proposal as part II. While Anscombe, in her 1977 Preface to RoC, dates this manuscript without any further argument to "Cambridge March 1951", von Wright proposes that it may have been written already in Summer 1950 when Wittgenstein was staying at von Wright's house at Cambridge. In the Editors' Preface, von Wright observes that

[i]n June 1950 Wittgenstein resided for some time in Cambridge. Professor von Wright remembers that he had a copy of Goethe's Farbenlehre with him; they studied the work together and discussed a lot of the logic of colours. It is possible that Wittgenstein at this time brought together his thoughts to the short section, which is published here. ${ }^{42}$

The proposal that the first part of MS 176 is to be dated to 1950 rather than 1951 is repeated in von Wright's "Wittgenstein Papers". ${ }^{4}$ Since this part of MS 176 has no dates, I do not think von Wright's dating - or at any rate, a date earlier than Anscombe's March 1951 is out of the question. Actually, von Wright's dating is in line with what Brian Rogers has recently suggested concerning the dating of this section into Summer 1950. ${ }^{44}$ It may well be that Wittgenstein made a summary of his earlier remarks on colour (written in MS 173 in the Spring and early Summer 1950) in an unused notebook already in $\mathrm{mid} /$ late 1950. In this case, he would have simply continued his much later - chain of remarks on knowledge, begun in MS 175, on

\footnotetext{
${ }^{42}$ Item I, p. 2. Compare Rothhaupt (1996: 381), who presents further evidence concerning von Wright's and Wittgenstein's 1950 discussions on colours. Rothhaupt, however, seems to think that it was probably MS 173, which Wittgenstein was working on during his two longer stays at von Wright's house in 4-25 April 1950 and 2-8 June 1950 (dates given by Rothhaupt). In any case, it is easy to agree with Rothhaupt's argument that the place given by Anscombe (1977) for MS 173, "Spring 1950, Oxford", can hardly be correct.

${ }^{43}$ von Wright (1982: 46) dating it simply to 1950: no more exact date is given.

${ }^{44}$ Rogers (2011: 69-73).
} 
MS 176, p.22r, where his earlier summary on colours ended. On the basis of the Bergen Nachlass Edition facsimiles on Wittgenstein Source, ${ }^{45}$ the summary seems, indeed, to be written with a different ink from the dated remarks that follow it. The ink resembles the one used in the first part of MS 175, written probably before or in September 1950. At any rate, it is practically certain that the summary was not written after MS 175 was already finished because the dates of MS 175 (last date 21.3. on p.74v) continue directly in MS 176 p. $22 \mathrm{r}$ where the undated summary ends (first date 21.3). ${ }^{46}$ The very fact that the first part of MS 176 contains no dates, unlike Wittgenstein's other remarks written in March 1951, may also be symptomatic of an earlier date.

If this is true, the von Wright - Anscombe controversy concerning the correct dating of MS 176 pp. 1-22r may teach us an important lesson: it is by no means clear that Wittgenstein's late manuscripts may be organized in a neat temporal order. Rather, Wittgenstein may have been either filling several notebooks simultaneously, or have continued a particular chain of remarks in another notebook, which already contained earlier remarks. Both are possible scenarios for the first half of MS 176. This, however, also means that von Wright's later proposal of having the last manuscripts simply published in their hypothetical temporal order would by no means be an unproblematic solution in presenting Wittgenstein's last writings to the public. ${ }^{47}$ The reason is that such an order of notebooks may not always be identical to the chronological sequence of remarks written in them. The latter may sometimes be established on the basis of a critical and philological study of the notebooks. ${ }^{48}$ In the particular case of MS 175 and MS 176, reading MS 176's

\footnotetext{
${ }^{45} \mathrm{http}: / /$ www.wittgensteinsource.org/BFE/Ms-176 f (accessed 15.5.2021).

${ }^{46} \mathrm{http}: / /$ www.wittgensteinsource.org/BFE/Ms-176,22r f (accessed 15.5.2021). For more arguments, see Rogers (ibid.). Rothhaupt (1996: 385-387) agrees that the summary can in principle be dated to 1950, but still favours the hypothesis that Wittgenstein worked on the summary in MS 176 simultaneously with his remarks on knowledge in MS 175 in March 1951.

${ }^{47}$ Joachim Schulte has recently suggested that such an approach would have been wiser than the thematic division (unpublished MS: 28); a similar proposal was made by David Stern (1996: 447).

${ }^{48}$ This is not a new proposal. Concerning MS 173 and 174, Josef Rothhaupt (1996: 382) has proposed that MS 174, begun in Cambridge in April 1950, may have been composed at least partly simultaneously with the later parts of MS 173.
} 
summary on colours directly after having finished MS 175 and before proceeding to p. 22r of MS 176, will almost certainly break the temporal order in which the remarks in MS 175 and 176 were originally written. Thus, printing them in the MS-order may also distort the argumentative sequence of Wittgenstein's remarks.

Considerations such as this may explain why the editors decided to edit the late notebooks as they did, especially given von Wright's $(1982,5)$ claim that their leading principle was to provide the reader with a "naked" text with minimal editorial comments. In the case of MS 175-177, they provided such a 'naked' text by restoring the temporal and argumentative sequence of Wittgenstein's remarks and by separating MS 176, pp. 1-22r from the rest of the notebook. This policy was adopted both in von Wright's 1967-8 edition and in the publication program that was realized. But was the reverse of this approach a particular "compartmentalization" of Wittgenstein's later thought, suppressing connections between the three main thematic complexes and giving an appearance of separate thematic investigations? - I think it was, and the effect was amplified by the unnecessarily long time between the publication of $O C$ and $L W 2$. It is thus easy to agree with scholars such as Stern, Schulte and Westergaard that this consequence was unfortunate. I do not wish to take a definite stand on the question whether von Wright's 1968 edition, trying to balance between faithful presentation and editorial intervention, would have offered a better solution. Neither shall I speculate further how Wittgenstein's latest thought would have been received, had von Wright's edition seen the printer's ink. But in any case, the issue of MS 176 shows that even though one may criticize Anscombe's, von Wright's and Rhees' editorial decisions in many different ways and for many good reasons, they seem to have been well aware that in the case of Wittgenstein's last notebooks, no solution is a solution without problems. 
Lassi Jakola / G.H. von Wright 


\title{
II. The Archival Items
}

\section{G. H. von Wright's edition of Wittgenstein's "Last Writings" (ca. 1967-1968)}

\author{
Von Wright and Wittgenstein Archives, \\ University of Helsinki
}

\author{
Archive box F1, item "Last Writings" \\ Signum: Witt-AM-F1
}

Item I. Vorwort der Herausgeber / Editors' Preface

Item II. Quotation from Wittgenstein's TS 222

Item III. Table of contents

Item IV. Random pages from the edition 


\section{Item I: Editors' Preface ${ }^{49}$}

\section{Editors' Preface $^{50}$}

This book presents the reader with notes from the last two years of Wittgenstein's life. In this period, Wittgenstein was preoccupied - exclusively, it seems - with three themes or groups of questions: ${ }^{51}$

The first theme concerns the distinction between the "inner" and the "outer", the relation of the "private" world of mental processes and states to the objectively observable things and events of the physical world, accessible to everybody. These questions, and what is said of them, are closely related to the considerations in the Philosophical Investigations and in Zettel.

The second theme could perhaps be called "The Logic of Colours". Remarks on the logic of colours appear all over in Wittgenstein's writings, sometimes even in greater extent - like in Philosophical Remarks. But never before did he focus on questions pertaining to this topic as he does in his notes from the year 1950 .

The third topic is epistemological and concerns the concepts of knowledge and certainty. In his other writings, Wittgenstein treated the topic only sparsely. But what he writes on the topic now forms a relatively self-contained whole. $^{52}$

The remarks on the "inner" and "outer" problem fall into three parts. ${ }^{53}$ The first - in the order which is reproduced here - was begun at the end of April $1950,{ }^{54}$ and the second was probably written around the same time as the first. ${ }^{55}$ The third ${ }^{56}$ which is only a few pages long, stems from April 1951. Wittgenstein interrupted then his writings on knowledge and certainty for a few days in order to return once again to this major problem of all his efforts.

\footnotetext{
${ }^{49}$ A normalized translation by Lassi Jakola. In the same archive file WWA: Witt-Am-F1, there is also a 4-paged typed sketch of this preface, with many hand-written alterations. The sketch is not reproduced here. See Part I, section 2, above.

${ }^{50}$ The plural form implies that, though based on von Wright's proposal, the edition was meant as a joint effort - in this case, between von Wright and Anscombe.

${ }^{51}$ This tripartite thematic division, it seems, was first introduced in von Wright's introduction to his transcription of the 'Omega Volumes' in 1962 (WWA: Witt-AM-F1). It informs the three major editions - OC, RoC and LW2 - from MSS 169-177. See also von Wright to Anscombe, 11 June 1964. NLF: The Georg Henrik von Wright Collection, Coll. 714, 11-12.

${ }^{52}$ The Preface to $O C$ is more emphatic on this point: "It constitutes a single treatment of the topic" (Anscombe and von Wright 1969: vie).

${ }^{53}$ This claim implies that, at this point, von Wright did not count MS 169, MS 170, and MS 171 among the materials to be described in this context: these three manuscripts were, however, later included in $L W 2$.

${ }^{54}$ MS $173,31 \mathrm{v}-47 \mathrm{v}$.

${ }^{55}$ MS 174, 1-14.

${ }^{56}$ MS 176, 46v-51v.
} 


\section{Vorwort der Herausgeber}

Was in diesem Buche dem Leser vorgelegt wird, sind Aufzeichnungen aus den zwei letzten Lebensjahren wittgensteins. ammIn diexser tetef Zeit hat sich wittgenstein, wie es scheint ausschliesslich,mit drei Themata oder Gruppen von Fragen beschättigt:

Das' erste Thema gilt die Distinktion zwischen "Innen" und "Aussen", das Verhältnis der "privaten" Welt der seelischen Vorgänge und Zustände zu den objektiv beobachtbaren und allen zugänglichen Dingen und Ereignissen der physischen Welt。 Diese Fragen, und was über sie gesagt wird, hängen eng mit den Erörterungen in den Philosophischen Untersuchungen und den

Zetteln zusammen.

Das zweite Thema könnte man "Ald Logik der Farben" nennen. Bemerkungen zur Farben-Logik finden sich zwar überall im Wittgensteins Schrifttum, manchmal sogar in grosser Fílle wie z.B.in deń Philosophischen Bemerkungen. Nie zuvor aber hat er sich so konzentriert mit den hierher gehörigen Fragen beschäftigt wie in beinef Aufzeichnungen vom Jahre 1950 。

Das dritte Thema ist erkenntnistheoretischer Art, die Begrifie des Wissens und der Sicherheit betreffend. In seinen anderen Schriften hat Wittgenstein es nur spärlich behandelt. Was er jetzt zu diesem Thema schrieb bildet ein verhältnismässig abgeschlossenes Ganzes.

Die Bemerkungen zum Problem "Innen - Aussen" zerfallen in drei Teile. Der erste in der hier wiedergegebenen Reihenfolge wurde Ende April 1950 begonnen; der zweite dïrfte zur ungefähr derselben Zeit der erste verfasst sein. Der dritte, der nur wenige Seiten umfasst, rührt vom April 1951 her. Wittgenstein hatte dann sein Schreiben über Wissen und Sicherheit für einige Tage unterbrochen, um nochmals zu diesem Hauptproblem aller seiner Bemühungen zurückzukehren。 
The notes concerning the logic of colours were probably begun on loose sheets in Wien in early $1950^{57}$ and continued in an empty notebook immediately after Wittgenstein's return to England. ${ }^{58}$ A part of them is dated late March and early April. After a brief excursion to the problem of the "inner" and "outer", 59 the author returns to colours in the very same notebook. ${ }^{60}$ Most of what he wrote on colour concepts on the loose sheets and in this notebook, he later crossed out with a line. This does not, however, mean that he would have abandoned what he had written. Rather, the procedure is clearly related to the following fact:

At the beginning of another notebook, Wittgenstein arranged a selection from his earlier remarks on colour. ${ }^{61}$ Sometimes he reproduced the crossed-out remarks in the summary word-for-word, sometimes he changed them in some respect, and sometimes he crammed, as it were, several remarks into one. Even though the earlier notes contain things which were not used in the summary and which may be of interest, the editors have - after some hesitation - decided to publish only the summary. ${ }^{62}$

In June 1950, Wittgenstein resided for some time in Cambridge. ${ }^{63}$ Professor von Wright remembers that he had a copy of Goethe's Farbenlehre with him; they studied the work together and discussed frequently the logic of colours. It is possible that Wittgenstein, at this time, compressed his thoughts into the short section, which is published here. ${ }^{64}$

By far, the greatest part of the notes concerns the concepts of knowledge and certainty. Wittgenstein seems to have got the decisive impetus to deal with these questions from conversations with Professor Norman Malcolm in Ithaca, N.Y. in the summer of $1949 .^{1}$ In the autumn, having

1 C.f. Norman Malcolm, Ludwig Wittgenstein, A Memoir, p. 87-93.

\footnotetext{
${ }^{57}$ MS 172, 1-4.

${ }^{58}$ MS 173, 1 ff.

${ }^{59}$ MS $173,31 \mathrm{v}-47 \mathrm{v}$.

${ }^{60}$ MS $173,47 \mathrm{v}$ ff.

${ }^{61}$ MS 176, 1-22r.

${ }^{62}$ This point was discussed in correspondence, with Anscombe favouring the publication of the earlier materials, while von Wright preferred to include the MS 176 summary only. In Anscombe's RoC (1977), the materials from all three manuscripts are reproduced. Compare von Wright to Anscombe 11 June 1964, 18 Jan 1965, 28 Jun 1965. NLF: The Georg Henrik von Wright Collection, Coll. 714, 11-12.

${ }^{63}$ Rothhaupt (1996: 381) notes that Wittgenstein's two longer stays at von Wright's house in Cambridge took place 4-25 April 1950 and 2-8 June 1950.

${ }^{64}$ Concerning the dating of MS 176, 1-22r, see Part I, section 8.
} 
Die Aufzeichnungen zur Farben-Logik wurden wahrscheinjich in Wien im Frïhahr 1950 auf losen Blättern angefangen und unmittelbar nach Wittgensteins Rückkehr nach England in einem noch unbeschriebenen Notizbuch fortgesetzt. Ein Teil von ihnen sind Ende März und Anfang April datiert。Nach einem kurzen Ausflug ins "AInnen - Aussen"-Problem kehrt der Verfasser im selben Notizbuch wieder zu den Farben zurück. Das allermeiste davon was uber Farbbegriffe geschrieben hat, hat er später mit einem Strich durchkreuzt. Das bedeutet jedoch nicht, dass er das Geschriebene verworfen hätte.Sondern"/hängt augenscheinlich mit Folgendem zusammen:

Im Anfang eines feiteren Notizbuch" hat Wittgenstein eine Auslese aus den früheren Aufzeichnungen über Farben zusammengestellt. Die durchkreukzten Bemerkungen hat er manchmal wortgetreu in die Zusammenfassung hinübergetragen,manchmal hat er sie etwas geändert, manchmal hat er mehrere in eine gleichsam zusammengedrängt。 Obwohl die früheren Aufzeichnungen manches enthalten, was nicht für die Zusammenfassung benutzt worden ist und vom Interesse sein könnte, haben die Herausgeber nach einigen Zögern sich dafür entschlossen nur diese)zu drucken. Im Juni 1950 hielt sich Wittgenstein eine Zeitlang in Cambridge auf。 Professor von Wright erinnert sich, dass er damals Goethes Farbenlehre bei sich hatte; sie haben zusammen das Werk studiert und viel über Farben-Logik gesprochen. Es ist möglich, dass Wittgenstein zu eben dieser Zeit seine Gedanken zu dem hier veröffentlichten kurzen Abschnitt zusammengefesst hat. Der weitaus grösste Teil der fiter gedruaken Bemerkungen behandeIn die Begriffe des Wissens und der Sicherheit. Den entscheidenden Anstoss lich mit diesen Problemed scheint Wittgenstein in Unterredungen mit Professor Norman Malcolm in Ithaca,N.Y. im Sommer des Jahres 1949 pekemmer zu haben。 ${ }^{\perp}$ Im Herbst, nach

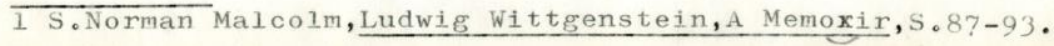


returned to England, he was ill and could not work. In late December, he travelled to Vienna, where ${ }^{65}$ he stayed until late March. He seems to have done some work in Austria - primarily related to the problem of knowledge and certainty ${ }^{66}$ After his return, he wrote down thoughts on these matters on two different occasions - as it seems, between April and September. ${ }^{67}$ For some months in autumn and winter, he wrote nothing. In March, after he had moved from Oxford to Cambridge, he was able to work well again. The most comprehensive of the four sections on knowledge and certainty was written between 10 March and 27 April at the house of his doctor in Cambridge. ${ }^{68} \mathrm{He}$ died on 29 April.

\footnotetext{
${ }^{65}$ I have interpreted the "we" in the German text as a typing error and read "wo" instead. ${ }^{66}$ MS 172.

${ }^{67}$ MS 174, $14 \mathrm{v}-40$ and MS 175, $1 \mathrm{r}-34 \mathrm{v}$, respectively.

${ }^{68}$ MS 175 35r-79; MS 176 22r-46v \& 51v-81 and MS 177, 1r-11. The doctor, Edward Bevan, was also von Wright's family doctor in Cambridge.
} 
England zurückgekehrt, war er krank und hat nicht arbeiten können. Ende Dezember fuhr er nach Wien, we er sich bis zum Ende März aufhieit. In österreich scheint er wieder ein wenig gearbeitet zu haben - und zwar hauptsächlich mit dem Problem des Wissens und der Sicherheit. Nach seinem kückkehr hat er noch im selben Jahre (zu zwei verschiedenen Gelegenheiten) utber diese Dinge Gedanken niedergeschrieben - wie es scheint im Zeitraume von rathund

April bis September. Fü einigez Monate im Herbst und Winter hat er/wie es dinkt|nichts resoluxieberf. Im März, hachdem er von Oxford nach Cambridge übergesiedelt war, hat er aber wieder gut gearbeitet. Der Aingsty der vier Abschnitte über wissen und Jwisthen und im Sicherheit wurde ivom 10.März zu 27.April in mause seines Artzes in Cambridge geschrieben。Er starb am 29.April. 


\section{Item II: Quotation from Wittgenstein's TS 222, 148-9 69}

(Connected with this: We should sometimes like to say "There must surely be a reason why-in a movement of a sonata, for example-just this theme follows that one." What we should acknowledge as a reason would be a certain relation between the themes, a kinship, a contrast or the like.-But we may even construct such a relation: an operation, so to speak, that produces the one theme from the other; but this serves only when this relation is one that we are familiar with. So it is as if the sequence of these themes had to correspond to a paradigm that is already present in us.

Similarly one might say of a picture that shews two human figures: "There must be a reason why precisely these two faces make such an impression upon us." That means: we should like to find this impression from the pair of faces again somewhere else-in another region.-But could we?

One might ask: what arrangement of themes together has a point, and what has no point? Or again: Why has this arrangement a point and this one none? That may not be easy to say! Often we may say: "This one corresponds to a gesture, this one doesn't.")

\footnotetext{
${ }^{69}$ A loose sheet of paper kept in the folder before the table of contents. The text passage is a quotation from Wittgenstein's TS 222, 148-9. In 1968, it had not been published; later it was printed as $\$ 171$ of the revised, third edition of RFM (1978). Presumably the quotation is meant as a motto of a kind for the whole edition, see Part I, section 7. The translation is by Anscombe, and has been taken from RFM (1978).

Between Items I and II, in the same folder (WWA: Witt-AM-F1), there is a 12 paged introduction, entitled "The Omega-volumes" to von Wright's transcription of the MSS 168-171 and 173-177 from 1962. The introduction contains von Wright's first impressions on the contents and value of these notebooks, along with a characterization of each transcribed item. Even though this item is of considerable interest for the earlier editorial history of Wittgenstein's last writings, it is much earlier than von Wright's proposed edition and is not reproduced here.
} 
Nordic Wittgenstein Review 10 |pp. 51-95|DOI 10.15845/nwr.v0i0.3598 |

(Damit hängt zusammen: Wir möchten manchmal sagen,"es muss doch einen Grund haben, warum auf dieses Thema - in einem Sonatensatz etwa - gerade d a s Thema folgt". Als Grund wirden wir eine gewisse Beziehung der beiden Themen, eine Verwandtschaft,einen Gegensatz, oder dergleichen, anerkennen. - Aber wir können ja eine solche Beziehung konstruieren: sozusagen eine Operation, die das eine Thema aus dem anderen erzeugt; aber damit ist uns nur gedient, wenn diese Beziehung eine uns wohlbekannte ist. Es ist also,als musste die Folge dieser Themen einem in uns schon vorhandenen Paradigma entsprechen.

Von einem Gemälde, das zwei menschliche Gestalten zeigt,könnte man ähnlich sagen: "Es muss einen Grund haben, warum gerade d i e s e zwei Gesichter uns einen solchen Eindruck machen." Wir möchten heisst das - diesen Eindruck der beiden Gesichter wo anders wieder finden - in einem anderen Gebiet. - Aber ob er wieder zu finden ist?

Man könnte auch fragen: Welche Zusammenstellung von Themen hat eine $\mathrm{P} \circ \mathrm{i} \mathrm{n} \mathrm{t} e$, welche $\mathrm{k}$ e i $\mathrm{n}$ e ? Oder: W a $\mathrm{r} u \mathrm{~m}$ hat diese Zusammenstellung eine Pointe und $\mathrm{d} i \mathrm{e}$ keine? Das mag nicht leicht zu sagen sein: oft können wir sagen: "Diese entspricht einer Geste,diese nicht.") 


\section{Item III: Table of Contents ${ }^{70}$}

Wittgensiein

L A S T W R I I N G S
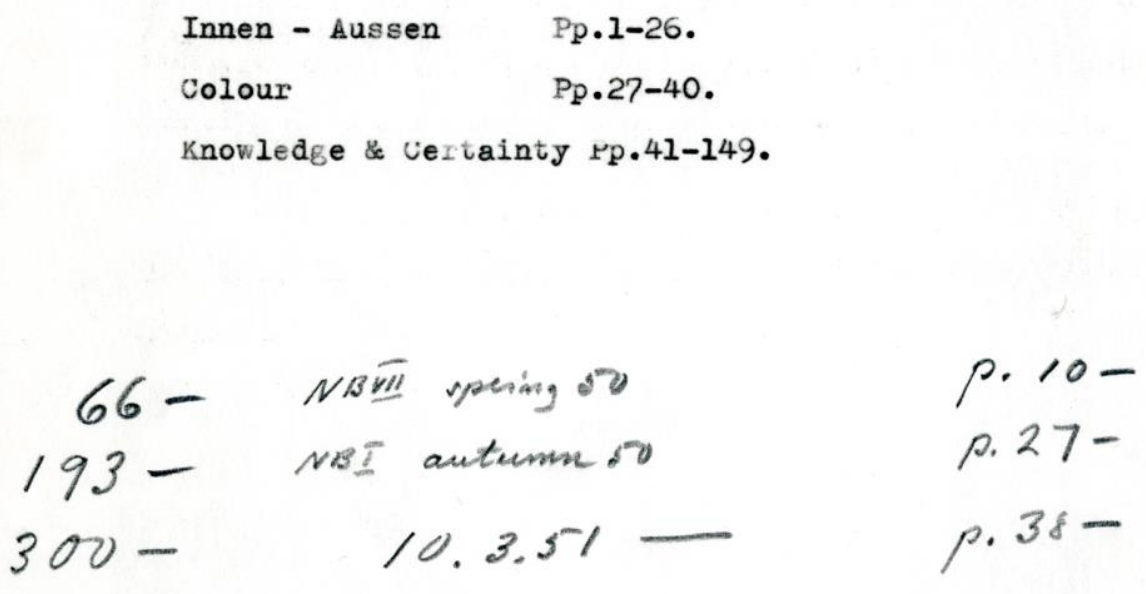

\footnotetext{
${ }^{70}$ The handwritten notes on this sheet are G. H. von Wright's references to the paragraph numbers and page numbers of $O C$, with the names and dates of the notebooks indicated in between. They may have been used for comparative purposes between von Wright's edition and the typeset pages of Anscombe's version in March 1969. See von Wright to Anscombe 10 March 1969, where he suggests that the separation of the three periods in which the remarks were written should be indicated in the edition with bars, giving the above remark and page numbers. These horizontal bars were added to the published version of OC. (NLF: The Georg Henrik von Wright Collection, Coll. 714, 11-12.)
} 


\section{Item IV: Random pages from the Edition ${ }^{71}$}

I

1. rp.1-11. April 1950 (ca).

2. Pp.12-22. April 1950, or later.

3. Pp.23-26. April 1951.

\footnotetext{
${ }^{71}$ I reproduce here all the random pages preserved in WWA archive folder Witt-AM-F1. For a preliminary hypothesis why exactly these pages have been preserved, see Part I, note 18 above. For a hypothetical correspondence between the sections indicated here, the underlying manuscripts and the later published editions, see Part I, sections 3 and 4.
} 
$-26-$

For instance, we could work with a mechanical "lie detector" and redefine a lie as that which causes a deflection on the lie detector.

So the question is: Would we change our way of living if this or that were provided for us? - And how could I answer that? ${ }^{72}$

\footnotetext{
${ }^{72}$ This passage corresponds to the end of the last - particularly long - remark in $L W 2$, source MS 176, 51 r-v. Judging from the page numbers, it would have been the final remark of section I.iii 'Innen-Aussen' of von Wright's edition. Translation by Luckhardt and Aue, taken from $L W 2$.
} 
Nordic Wittgenstein Review 10 |pp. 51-95|DOI 10.15845/nwr.v0i0.3598 |

\author{
$-26-$ \\ Wir kônnten - z.B. - mit einem mechanischen "Lúgent-Detektor" \\ arbeiten und eine Luge neu definieren,als dasjenige was einen \\ Ausschlag des Lügen-Detektors erzeugt. \\ Würden wir also unsre Lebensform ändern,wenn uns das \\ und das zur Verfügung gestellt würde? - Wie könnte ich diese \\ Frage beantworten?
}


${ }^{73}$ The corrected page-numbering on this page shows, I believe, that von Wright also considered another order for the materials. In this plan, the section on colours would probably have been preceded by the notes on knowledge (later Section III), since this section is roughly 100 pages long. This idea may be related to the early draft of a preface, contained in Witt-AM-F1, where the material on 'Innen-Aussen' was not included. (See Part I, section 2 and note 49, above). 
III

K N OW L E D G E A N D C E K T A I N T Y

1. Hp.41-52. January - March 1950.

2. rp.53-72. April 195u, or later.

3. rp.73-87. September 195u,or earlier.

4. rp.88-149. Karch 10,1951 - april 27,1951. 
I make assertions about reality, assertions which have different degrees of assurance. How does the degree of assurance come out? What consequences has it?

We may be dealing, for example, with the certainty of memory, or again of perception. I may be sure of something, but still know what test might convince me of error. I am e.g. quite sure of the date of a battle, but if I should find a different date in a recognized work of history, I should alter my opinion, and this would not mean I lost all faith in judging. ${ }^{74}$

\footnotetext{
${ }^{74}$ Translation by Paul and Anscombe. This remark corresponds to OC \$66, source MS $174,14 \mathrm{v}-15 \mathrm{r}$. A double horizontal line occurs before this remark in the MS. This is the first remark from MS 174 included in $O C$, and it would have commenced section III.ii in von Wright's projected edition. This remark shows that von Wright's edition did not, at this point, have a running numbering for the individual remarks.
} 
Nordic Wittgenstein Review 10 |pp. 51-95|DOI 10.15845/nwr.v0i0.3598 |

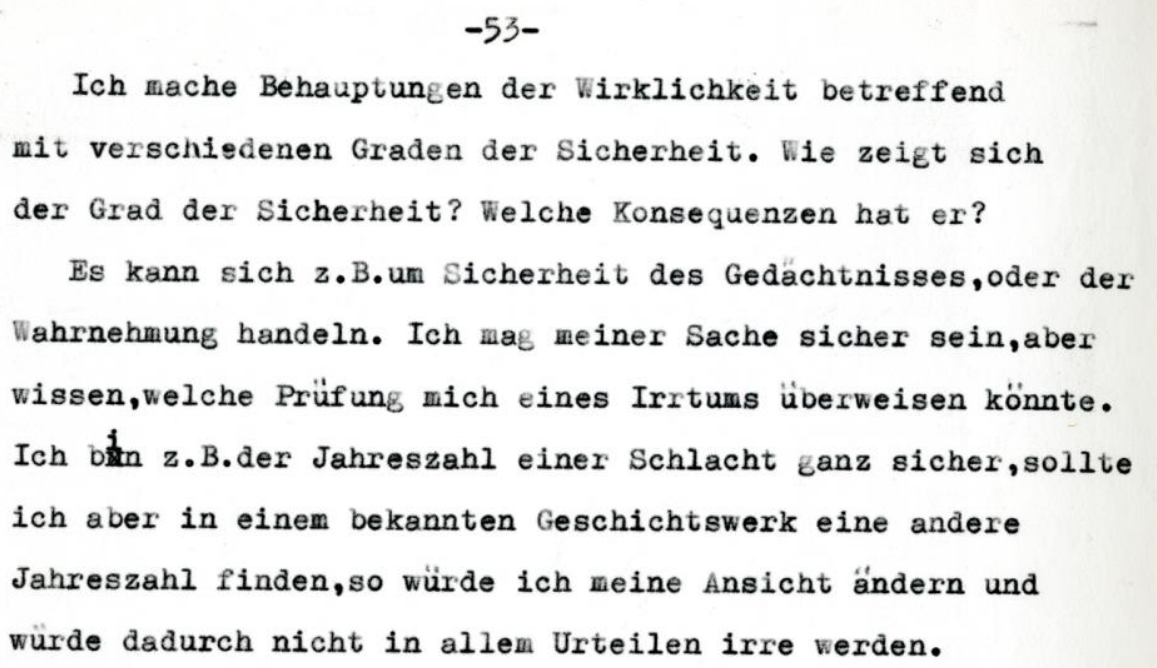


$-88-$

10.3.51.

Not all corrections of our views are on the same level.

Supposing it wasn't true that the earth had already existed long before I was born-how should we imagine the mistake being discovered?

It's no good saying "Perhaps we are wrong" when, if no evidence is trustworthy, trust is excluded in the case of the present evidence.

If, for example, we have always been miscalculating, and twelve times twelve isn't a hundred and forty-four, why should we trust any other calculation? ${ }^{75}$

\footnotetext{
${ }^{75}$ This chain of remarks corresponds to OC $\iint 300-303$; translation by Paul and Anscombe, with the numbering of remarks removed. In MS 175, p. 35r, these remarks commence the chain of dated remarks running through the rest of MS 175, MS 176 22r ff., and MS 177. In von Wright's edition, they would have marked the beginning of Section III.4. Note the lack of numbering for the remarks. Quite interestingly, the page does not contain the final sentence of $O C \$ 300$, immediately continuing the final remark printed on this sheet: "Und das ist natürlich falsch ausgedrückt" - "And of course that is wrongly put". This does not, however, necessarily signify an omission; the final sentence may have been printed on the next page. See also note 18, above.).
} 
Nordic Wittgenstein Review 10 |pp. 51-95|DOI 10.15845/nwr.v0i0.3598 |

$$
-88-
$$

10.3 .51 .

Nicht alle Korrekturen unsrer Absichten stehen auf der gleichen stufe.

Angenommen,es sei nicht wahr, dase die Erde schon lange $x$ vor meiner Geburt existiert hat,wie hat man sich die Entdeckung dieses Fehlers vorzustellen?

Es ist nichts nutz zu sagen "Vielleicht irren wir uns", wenn,wenn keiner Evidenz zu trauen ist,im Fall der gegenwärtigen Evidenz nicht zu trauen ist.

Wenn wir uns z.B.immer verrechnet haben und $12 \times 12$ nicht 144 ist,warum sollten wir dann irgendeiner anderen kechnung trauen? 


\section{Bibliography}

\section{A. Published primary and secondary sources:}

Anscombe, E., 1977. "Vorwort des Herausgebers”. In: Wittgenstein (1977a). Anscombe, E. and G. H. von Wright, 1969. "Vorwort der Herausgeber". In: Wittgenstein (1969).

van Gennip, K., 2003. "Connections and Divisions in On Certainty". In: Winfried Löffler et al., eds., Knowledge and Belief. Papers of the $26^{\text {th }}$

International Wittgenstein Symposium 3-9 August 2003, Kirchberg am Wechsel, Austrian Ludwig Wittgenstein Society, 129-131.

Jakola, L., (to appear). “Approaches to Wittgenstein's 'Last writings' (1949_

51): Elizabeth Anscombe, G. H. von Wright and Rush Rhees in

Dialogue". In: T. Wallgren, ed., The Creation of Wittgenstein,

Bloomsbury.

Paul, D., 2007. Wittgenstein's Progress. The Wittgenstein Archives at the University of Bergen.

Pichler, A., 1993. "A Source Catalogue of the Published Texts". In M. Biggs and A. Pichler, Wittgenstein: Two Source Catalogues and a Bibliography, Working Papers from the Wittgenstein Archives at the University of Bergen, No. 7.

Rhees, R., 2003. Wittgenstein's On Certainty. There, like our life, ed. D. Z. Phillips. Oxford: Blackwell.

Rogers, B., 2011. Philosophical Method in Wittgenstein's On Certainty. PhD Diss. University of California, Irvine.

Rothhaupt, J., 1996. Farbthemen in Wittgenstein's Gesamtnachlaß. Weinheim: Beltz Athenäum Verlag.

Schulte, J. (unpublished MS). Wittgenstein on Certainty and Doubt. $6^{\text {th }}$ complete draft.

Stern, D., 1996. “The Availability of Wittgenstein's Philosophy”. In: H. Sluga \& D. G. Stern, eds., The Cambridge Companion to Wittgenstein. Cambridge: Cambridge University Press, 442-476.

Westergaard, P., 2017. "A Note on Rhees, the Bemerkungen über Frazers "The Golden Bough” and Über Gewißheit”. In: Chr. Limbeck-Lilienau and Fr. Stadler, eds., The Philosophy of Perception and Observation. Contributions of the $40^{\text {th }}$ International Wittgenstein Symposium, August 6-12, 2017. Austrian Ludwig Wittgenstein Society, 228-291.

Westergaard, P., 2019. "A note on MS 174 - The meaning of a remark is given by the stream of the text". In: A. Siegetsleitner et al., eds., Crisis and Critique: Philosophical Analysis and Currents events. Contributions of the 
42 International Wittgenstein Symposium. August 4-6, 2019, Kirchberg am

Wechsel. Austrian Wittgenstein Society, 270-272.

Wittgenstein, L., 1969. On Certainty, eds. E. Anscombe and G. H. von

Wright, transl. E. Anscombe. Oxford: Basil Blackwell. (Abbreviated as $O C)$

Wittgenstein, L. 1974. Bemerkungen über die Grundlagen der Mathematik, hrsg. G.

H. von Wright, R. Rhees und E. Anscombe. Erweiterte und revidierte

Neuausgabe. Frankfurt am Main: Suhrkamp.

Wittgenstein, L., 1977a. Remarks on Colour, ed. and transl. E. Anscombe.

Oxford: Basil Blackwell. (Abbreviated as $\mathrm{RoC}$ )

Wittgenstein, L., 1977b. Vermischte Bemerkungen, ed. G. H. von Wright in

collaboration with H. Nyman. Frankfurt am Main: Suhrkamp.

(Abbreviated as VB)

Wittgenstein, L., 1982. Last Writings on the Philosophy of Psychology, vol. 1, eds.

G. H. von Wright and H. Nyman, transl. C. G. Luckhardt and M. A.

E. Aue. Oxford: Basil Blackwell. (Abbreviated as LW1)

Wittgenstein, L., 1992. Last Writings on the Philosophy of Psychology, vol. 2, eds.

G. H. von Wright and H. Nyman, transl. C. G. Luckhardt and M. A.

E. Aue. Oxford: Basil Blackwell. (Abbreviated as LW2)

Wittgenstein, L., 2015-. Bergen Nachlass Edition, ed. the Wittgenstein Archives at the University of Bergen under the direction of Alois Pichler. In: Wittgenstein Source, curated by Alois Pichler (2009-) and Joseph Wang-Kathrein (2020-) [wittgensteinsource.org]. Bergen: Wittgenstein Archives.

von Wright, G. H., 1954. "Ludwig Wittgenstein, En biografisk skiss". Ajatus 18, 5-23. First English version "Ludwig Wittgenstein, A biographical Sketch" published in Philosophical Review LXIV, 1955, 527-545. von Wright, G. H., 1971. Explanation and Understanding. Ithaca, NY: Cornell University Press.

von Wright, G. H., 1972. "Wittgenstein on Certainty”. In: G. H. von Wright, ed., Problems in the Theory of Knowledge / Problèmes de la Théorie de la Connaisance. Entrentiens in Helsinki, 24-27 August 1979. Hague: Martinus Nijhoff, 47-60. Revised reprint in von Wright 1982.

von Wright, G. H., 1977. "Vorwort des Herausgebers". In: Wittgenstein (1977b).

von Wright, G. H., 1982. Wittgenstein. Oxford: Basil Blackwell. von Wright, G. H., 1989. "Intellectual Autobiography". In: L. E. Hahn and P. A. Schilpp, eds., The Philosophy of Georg Henrik von Wright. La Salle (IL): Open Court, 3-55.

von Wright, G. H., 1998. In the Shadow of Descartes. Dortrecht: Kluwer Academic Publishers.

von Wright, G. H., 2001. Mitt liv som jag minns det. Helsingfors: Söderström \& Co. förlags Ab. 
von Wright, G. H. and H. Nyman, 1992. “Vorwort der Herausgeber”. In Wittgenstein (1992).

\section{B. Unpublished sources and archival materials:}

\section{B.1. The National Library of Finland. (NLF)}

COLL. 714, 11-12: The correspondence between G. H. von Wright and Elizabeth Anscombe.

COLL. 714, 142-148: The correspondence between G. H. von Wright and Norman Malcolm.

COLL. 714, 200-201: The correspondence between G. H. von Wright and Rush Rhees.

\section{B.2. Von Wright and Wittgenstein Archives, University of Helsinki (WWA)}

Von Wright materials:

Wri-FC-004 and Wri-FC-006: The correspondence between G. H. von Wright and Rush Rhees.

Wri-FC-016: The correspondence between G. H. von Wright and Blackwell publishing.

Wri-SF-064-c: G. H. von Wright: "Wittgenstein on Certainty", a 15-paged originally clipped typescript with minor handwritten corrections. (1970). A typescript draft of von Wright 1972, 15pp.

Wittgenstein materials:

Witt-000. G. H. von Wright: "Wittgenstein materials kept with the Department of Philosophy".

Witt-100-082. A bound photographic copy of the 'Omega volumes', $\Omega_{1}$, containing MSS 168, 169, 170, 171, 175 and 169.

Witt-100-085. A bound photographic copy of the 'Omega volumes', $\Omega_{1}$, containing MSS 173, 174, 176 and 177.

Witt-500-012. Materials related to Rush Rhees, including the catalogue "The Rhees Materials" by von Wright, dated Nov 1990.

Witt-AM-F1. Described by G. H. von Wright as "Materials for the Last Writings on the Philosophy of Psychology. With GhvW's sketches of a preface and comments on the manuscripts. The book as then projected was never published."

Witt-AM-H9. Described by G. H. von Wright as "Revisions and corrections of Wittgenstein-texts. Plan (abandoned) for a revised edition.” 


\section{Biographical note}

Lassi Jakola is a doctoral student in Classics and Philosophy at the University of Helsinki. Presently, he is finalizing his doctoral dissertation on G. H. von Wright's Varieties of Goodness (1963). Besides von Wright, his research focuses on the sophistic movement $\left(5^{\text {th }}\right.$ century BCE), early Greek philosophical terminology, and the editorial history of Wittgenstein's writings. 